\title{
SCIENTIFIC RESEARCH IN ANTARCTICA
}

$\mathrm{T}$

HE Antaretic Treaty signed at Washington on December 1, 1959, by the British Government and by twelve others, all with interests, scientific or otherwise, in the Antarctic, including all seven claimants to the Antarctic's territories, recognized, in a preamble, that it is in the interests of all mankind that Antarctica should continue to be used exclusively for peaceful purposes and should not become the scene or object of international discord. The Treaty also recognized the extreme importance of seientific work and the firm foundation for the continuation of that work resulting from the International Geophysical Year.

In a short debate on the Antarctic in the House of Lords on February 18, opened by Lord Shackleton, who asked when the Government expected the Treaty to be ratified and what its policy was with regard to the future Antarctica, Lord Shackleton stressed the great value of the Antarctic as a source of scientific information. While that scientific interest had led to a remarkable degree of international co-operation, Lord Shackleton was somewhat concerned as to the possibility and effect of development, geologically and in other ways. In particular, he asked what provision had been made for the continuing discussion contemplated under Article 9 of the Treaty and what type of administration the Government had in mind. The Bishop of Norwich, who asked for a Government assurance that the British contribution in Antarctic investigation and research under the Treaty would not be less than that at present existing, also stressed the value of Antarctic research in longrange weather forecasting, geophysics, glaciology and some branches of biology; and after a tribute to the work done by Great Britain in the past, he emphasized the value of the opportunity for international collaboration in scientific work which the Antarctic offered.

Lord Lansdowne, who replied for the Government, said that it hoped to ratify the Treaty at an early date and that the Government's policy was to promote the basic aims of the Treaty. The Treaty should ensure the use of Antarctica for peaceful purposes only and it was hoped that it had established a firm foundation for scientific co-operation. The Government would have preferred a more comprehensive system of administration, but this could not be achieved at the conference. The ques. tion of some form of permanent secretariat was now under discussion. On the exohange of strictly scientific information and the planning of research, which came under Article 3, the Government considered that governments should not attempt to supersede the existing organizations such as the Special Committee on Antarctic Research, which had been working effectively since 1958. This Article, in fact, said : "every encouragement shall be given to the establishment of co-operative working relations with those Specialized Agencies of the United Nations and other international organizations having a scientific or technical interest in Antarctica". He hoped we would continue to make full use of such recently created organization and of the Specialized Agencies of the United Nations. The Government expected the Falkland Islands Dependency Survey, which was a principal contributor to Antarctic research, to continue, and those people most immediately affected by the Treaty, such as observers, exchange scientists and their staffs were, in fact, covered by the juridical and administrative arrangements.

\section{VISUAL PIGMENT OF THE HORSESHOE CRAB, LIMULUS POLYPHEMUS}

\author{
By $D_{R}$ RUTH HUBBARD and Frof. GEORGE WALD \\ Biological Laboratories, Harvard University, Cambridge, Mass.
}

\begin{abstract}
$\mathrm{O}$ WING mainly to the work of Hartline, the eye of the horseshoe crab, Limulus, has long been a classic object for electrophysiological investigation. This was the first eye in which electrical responses were recorded from single visual receptors'. The large size of these units and the relative simplicity of their nervous connexions have permitted a degree of analysis not achieved with other types of visual element ${ }^{2}$. This growing body of electrophysiological information lends special interest to the chemistry of the underlying processes.

We have now extracted the visual pigment of Limulus. This is the fourth arthropod visual pigment to be examined and the first such pigment obtained from an arachnoid. Two visual pigments have been extranted earlier from crustaceans, one from a euphausiid $^{3}$, the other from a decapod, the lobster ${ }^{4}$; and a visual pigment has also been obtained from an insect, the honey-be $\theta^{5}$.
\end{abstract}

The principal results of our experiments are summarized in Fig. 1. From a fraction of the eye tissues which we believe consisted largely of frag. ments of rhabdomeres, we have extracted a photosensitive pigment with $\lambda_{\max } 520 \mathrm{~m} \mu$. The chromophore of this pigment is retinene ${ }_{1}$. We therefore consider it to be a rhodopsin. On exposure to light it bleaches to a mixture of retinene and opsin. This behaviour, eharacteristic of vertebrate rhodopsins, distinguishes the Limulus pigment sharply from certain other invertebrate rhodopsins-squid, octopus, cuttlefish, Iobster - which under physiological conditions do not bleach but yield in the light relatively stable red-orange metarhodopsins, in which retinene remains attached as chromophore to opsin ${ }^{4}, 6$.

The curve shown in Fig. 1 is a difference spectrum measured in the presence of hydroxylamine. This reagent combines with retinene ${ }_{1}$ to form retinene ${ }_{1}$ 